\section{Nitration in Sulphuric Acid}

In the nitration of $2: 4$-dinitrotoluene in homogeneous solution in 87-100 per cent sulphuric acid media ${ }^{1}$, the effective nitrating agent is the nitronium $\left(\mathrm{NO}_{2}{ }^{+}\right)$ion. The velocity coefficient $k_{2}$ of the equation

$$
d\left[A r \mathrm{NO}_{2}\right] / d t=k_{2}[\mathrm{ArH}]\left[\mathrm{HNO}_{3}\right]
$$

(which is valid for fixed initial conditions only) has a maximum (first discovered by Martinsen ${ }^{3}$ ) in 92.0 per cent sulphuric acid at $90^{\circ}$.

We have now extended the experiments to the nitration of $(a)$ nitrobenzene, $(b)$ p-chloronitrobenzene, and (c) the trimethylphenylammonium ion (introduced as its nitrate), all at $25^{\circ}$. The diagram shows the variations of $k_{2}$ with medium composition.

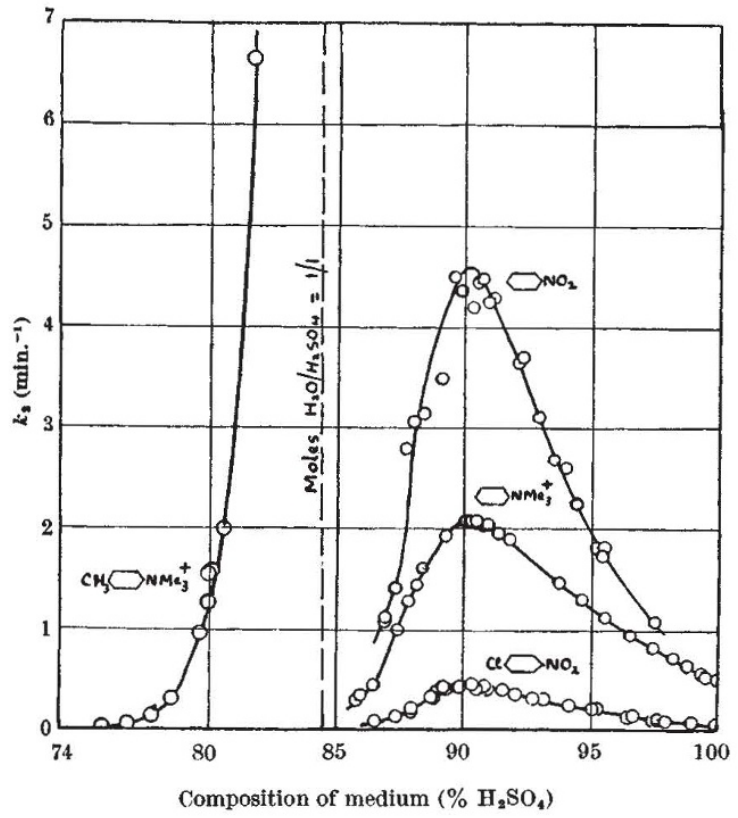

Experimentally, the results show (i) that, as nearly as can be judged, all three substances are nitrated most rapidly, at $25^{\circ}$, in the same optimum medium of approximately 90.4 per cent sulphuric acid; (ii) that relative rates of nitration for these compounds do not vary greatly with medium composition ${ }^{10}$.

\begin{tabular}{|c|c|c|c|c|}
\hline $\begin{array}{l}\text { Medium, } \\
k_{2}(a) / k_{2}(b)\end{array} \mathrm{H}_{2} \mathrm{SO}_{4}$ & & & & \\
\hline
\end{tabular}
$k_{2}(a) / k_{2}(b)$
$k_{3}(c) / k_{2}(b)$

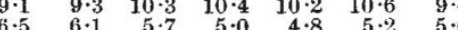

These kinetic features are consistent with the previous supposition $^{1}$ that, in the equation

$$
\mathrm{NO}_{2}^{+}+A r \mathrm{H}+B=A r \mathrm{NO}_{2}+B \mathrm{H}^{+},
$$

an acceptor molecule $B$, furnished by the medium, plays a part in determining the rate of nitration in a highly acid environment; but doubt is thrown on the validity of this hypothesis by Melander's demonstration ${ }^{11}$ that a tritium atom and a protium atom are replaced at the same rate in the nitration of toluene to dinitrotoluene.

The trimethyl-p-tolylammonium ion, which stands structurally to the trimethylphenylammonium ion as $p$-nitrotoluene does to nitrobenzene, is rapidly nitrated (see diagram) in media in which the molar ratio $\mathrm{H}_{2} \mathrm{O} / \mathrm{H}_{2} \mathrm{SO}_{4}$ exceeds unity. The same conclusion follows, for benzen $\Theta^{7}$ and toluene ${ }^{8}$, from a comparison of their two-phase nitrations with those of nitrobenzene ${ }^{5}$ and dinitrotoluene ${ }^{6}$. Chemical and physical evidence (especially Raman spectra ${ }^{4}$ ) shows that no substantial concentrations of nitronium ion can exist in such media. The nitrating agent may be the $\mathrm{H}_{2} \mathrm{NO}_{3}{ }^{+}$ion ${ }^{9}$, or, perhaps more probably, the $\mathrm{NO}_{2}{ }^{+}$ ion, present in very small concentration.

This note is published by kind permission of the Chief Scientist, Ministry of Supply.

\section{T. G. BONNER Margaret E. James AILSA M. LOWEN GWYN WILLIAMS}

\section{Royal Holloway College \\ (University of London), Englefield Green,} Surrey.

Nov. 25. (Revised, May 10.)

${ }^{1}$ Bennett, G. M., Brand, J. C. D., James, D. M., Saunders, T. G., and Williams, G., J. Chem. Soc., 474 (1947).

${ }^{2}$ Bennett, Brand and Williams, $J$. Chem. Soc., 869, 875, 880 (1946). Hughes, E. D., Ingold, C. K., et al., Nature, 158, 448, 480 (1946). Westheimer, F. H., and Kharasch, M. S., J. Amer. Chem. Soc. 68, 1871 (1946)

' Martinsen, H., Z. physik. Chem., 50, 385 (1904); 59, 605 (1907).

- Chédin, J., Ann. Chim., [xi], 8, 243 (1937). Mem. Services Chim. de l'Etat, 31, 113 (1944). Chédin, Fénéant, S., and Leclere, R. C.R. Acad. Sci. Paris, 224, 1008, 1058 (1947).

'Hetherington, J. A., and Masson, I., J. Chem Soc., 105 (1933).

- Bennett, Williams, et al., J. Chem. Soc, 1185 (1947); J. Soc. Chem. Indust., 66, 288 (1947).

${ }^{7}$ Lewis, W. K., and Suen, T. J., Indust. Eng. Chem., 32, 1095 (1940).

${ }^{-}$McKinley, C., and White, R. R., Trans. Amer. Inst. Chem. Eng. 40,143 (1944).

- Cf. Halberstadt, E. S.. Hughes and Ingold, Nature, 158, 514 (1946). ${ }^{10} \mathrm{cf}$. Gillespie, R. J., and Millen, D. J., Quart. Rev. Chem. Soc., 2, 277 (1948).

${ }^{11}$ Melander, L., Nature, 163, 499 (1949). cf. Hughes, Ingold, et al., ibid.

\section{Separation of 2 : 4 Dinitrophenyl Amino- acids on Buffered Silica Gel}

For some time past I have been making a study of the free amino groups of the peptides liberated by papain and sodium bisulphite acting on wool keratin ${ }^{1}$, using Sanger's methods ${ }^{2,3}$. At an early stage it was found that 'non-absorbent gels' which were of service in separating $\mathrm{N}$-acetyl amino-acids were of little use in separating $2: 4$ dinitrophenylamino-acids, which all ran together as a single fast band using chloroform as solvent. Phillips and Stephen ${ }^{4}$ and Consden, Gordon, Martin and Synge ${ }^{5}$ have previously commented on the difficulty of preparing suitable gels with reproducible properties. Sanger ${ }^{2}$ and Consden et al. ${ }^{5}$ considered that silica gels which permitted satisfactory separations 'absorbed' the dinitrophenyl amino-acids to some extent. I have observed that successful separations of these acids on silica gel can be achieved by using concentrated phosphate buffers instead of water as the stationary phase ; by varying the $p H$ of the buffer, the rate of movement of the band of a particular acid can be varied within wide limits, the higher the $p \mathbf{H}$ the slower being the rate.

In general, with a given solvent the most successful separations are brought about by using the most alkaline buffers, although the rates of band movement may then become very slow and 'tailing' be pronounced. In practice, a compromise is made between completeness of separation and speed at which the 